\title{
MEASUREMENT OF THE RESISTANCE TO THE AQUEOUS FLOW BY THE ELECTRONIC TONOMETER*

\author{
RESULTS IN CASES OF CONGESTIVE GLAUCOMA \\ BEFORE AND AFTER TREATMENT
}

BY

\section{R. WEEKERS AND E. PRIJOT}

Department of Ophthalmology, University of Liége, Belgium

THE compression test performed with the electronic tonometer, combined with the use of Friedenwald's tables, makes it possible, to measure the resistance to the aqueous flow (Moses and Bruno, 1950; Grant, 1950; Prijot and Weekers, 1952).

In normal subjects, the coefficient of resistance varies from 2.9 to 7.3 , the average being 4.5 (Prijot and Weekers, 1952).

We have measured the resistance to the aqueous flow in patients suffering from simple non-congestive glaucoma, before and after medical or surgical treatment. This part of our research, which has only recently been published (Prijot and Weekers, 1952a; Weekers and Prijot, 1952a, b, c), may be summarized as follows:

(a) In untreated non-congestive glaucoma, the resistance to the flow is usually increased, the increase being proportional to the degree of hypertension. The exact location of the pathological changes responsible for the increased resistance is still not known and subject to discussion (Ascher and Spurgeon, 1949; Goldmann, 1951; Thomassen, 1947; Weekers and Prijot, 1952a).

(b) The hypotensive action of pilocarpine in non-congestive glaucoma is essentially due to its reduction of the resistance to the aqueous flow (Ascher, 1942; Löhlein, 1950; Thomassen, Perkins, and Dobree, 1950; Grant, 1951; Prijot and Weekers, 1952b).

(c) Iridencleisis reduces resistance to the aqueous flow; this lessened resistance results either from fistulization or from improved aqueous flow through the natural channels (Weekers and Prijot, 1952c).

(d) On the other hand, retrociliary diathermy does not diminish resistance to the flow, and its hypotensive action is due to a decrease in the formation of the aqueous (Weekers and Prijot, 1952b).

The present paper relates our observations in congestive glaucoma. To avoid misunderstanding, we propose to define congestive glaucoma as follows:

We consider glaucoma to be congestive when the irido-corneal angle is completely closed during the hypertensive phase. The hypertension may be accompanied by a redness of the eye, but this inflammatory character is not constant and may be absent. The daily or periodic variations are often great. In congestive glaucoma, papillary excavation and perimetric defects result from intra-ocular hypertension.

- Received for publication April 25, 1952. 
They are most evident when hypertension has been of high degree and of long duration.

These criteria of classification, which are similar to those adopted by Goldmann (1951) and Duke-Elder (1952), differentiate congestive glaucoma from the non-congestive condition; in the latter, the irido-corneal angle is either narrow or wide, but never closed. The three main symptoms (hypertension, papillary excavation; and perimetric defects) may progress independently of each other. There are also incomplete non-congestive glaucomas, glaucoma without hypertension being the most characteristic (Weekers, 1947).

\section{Principle of the Compression Test}

The compression test that we use is similar to that already proposed by Grant (1950). It has already been described (Prijot and Weekers, 1952a), but we shall briefly recall its principle.

Normally the ocular tension varies but slightly. This means that the volume of the liquid which penetrates the eye is equal to that which escapes during a given time. Placing a tonometer on the cornea changes this equilibrium; the foot of the tonometer raises the intra-ocular pressure and distends the sclera.

If the tonometer is kept in place for a prolonged period, the escape of fluid exceeds its formation and the intra-ocular pressure falls progressively. Several observations by Grant (1950) and ourselves (Prijot and Weekers, 1952a) demonstrate that the fall in tension is mainly due to a reduction in volume of the aqueous humour.

According to Goldmann (1951), the flow of the aqueous humour from the anterior segment of the eye obeys relatively simple laws. Poiseuille's law can be applied:

$$
F=\frac{P f}{R}
$$

$F$ is the flow of aqueous humour expressed in cmm. per minute. $P f$ is the outflow pressure of the aqueous humour, that is to say the intra-ocular pressure (Poc) minus the venous pressure at the point where the aqueous joins the blood $(P v) . \quad R$ is the resistance offered to the passage of the aqueous humour from the anterior chamber to the point where $P v$ is measured.

When the tonometer is placed on the globe, the pressure and the rate of flow of the aqueous are increased. In other researches we have shown that, on the contrary, the resistance remains constant (Prijot and Weekers, 1952a).

Friedenwald's tables (Moses and Bruno, 1950) permit calculation of the increase of $P o c$ during the compression test. Tonometric pressure $(P t)$ is the pressure of the globe when the tonometer is placed on the cornea, $P t_{1}$ is the tonometric pressure at the beginning of the test, and $\mathrm{Pt}_{\mathbf{2}}$ the tonometric pressure at the end of the test (i.e., after 5 minutes). The average tonometric pressure during the course of the test is calculated accurately enough by the arithmetic mean:

$$
P t_{1}+P t_{2}
$$


The average increase in pressure during the test is established by the formula:

$$
\frac{P t_{1}+P t_{2}}{2}-P o c
$$

On the other hand, Friedenwald's tables (Grant, 1950) show the increase in the flow of the aqueous humour during the compression test.

$V_{1}$ is the reduction in volume of the globe at the beginning of the test, and $V_{2}$ the reduction in volume at the end of the test. Friedenwald's tables take into account the indentation of the cornea and retraction of the sclera.

The volume of liquid forced out of the globe during the test is $V_{2}-V_{1}$. The quantity of liquid forced out per minute is:

$$
\frac{V_{2}-V_{1}}{5}
$$

During the compression test:

$$
R=\frac{P f+\frac{P t_{1}+P t_{2}}{2}-P o c}{F+\frac{V_{2}-V_{1}}{5}}
$$

Since $R$ is not modified during the test, and since Poiseuille's law postulates that $R=\frac{P f}{F}$,

$$
R=\frac{\frac{P t_{1}+P t_{2}}{2}-P o c}{\frac{V_{2}-V_{1}}{5}}
$$

Consequently the compression test performed with the electronic tonometer allows direct measurement of the resistance to the aqueous flow outside the globe.

\section{Results}

The coefficient of the resistance in normal subjects varies from 2.9 to 7.3, the average being 4.5 .

In every case of congestive glaucoma, the compression test reveals a considerable increase in resistance during the hypertensive phase (Table I).

The measurement of the resistance in the fellow eye during the hypertensive phase of the glaucomatous eye reveals, in some cases, a marked increase of resistance without any pathological rise in tension. This seems to result from a consensual phenomenon. 
The instillation of pilocarpine decreases the resistance providing it lowers the ocular tension (Table I).

TABLE 1

\begin{tabular}{|c|c|c|c|c|c|c|}
\hline \multirow{2}{*}{$\begin{array}{l}\text { Case } \\
\text { No. }\end{array}$} & \multirow{2}{*}{ Eye } & \multirow{2}{*}{ Date } & \multicolumn{2}{|c|}{ Without Treatment } & \multicolumn{2}{|c|}{ With Pilocarpine } \\
\hline & & & $\begin{array}{l}\text { Ocular } \\
\text { Tension }\end{array}$ & Resistance & $\begin{array}{l}\text { Ocular } \\
\text { Tension }\end{array}$ & Resistance \\
\hline $1134 / 51$ & Left & $\begin{array}{l}20 / 3 / 51 \\
21 / 3 / 51\end{array}$ & $\begin{array}{l}36 \cdot 8 \\
-\end{array}$ & $\underline{32 \cdot 2}$ & $\overline{17 \cdot 5}$ & $\overline{5 \cdot 8}$ \\
\hline \multirow{2}{*}{$754 / 52$} & Right & $\begin{array}{l}20 / 2 / 52 \\
21 / 2 / 52 \\
26 / 2 / 52 \\
27 / 2 / 52\end{array}$ & $\begin{array}{l}\frac{54}{3 \overline{4} \cdot 5} \\
.\end{array}$ & $\frac{57}{27}$ & $\frac{8}{11 \cdot 9}$ & $\begin{array}{l}3 \cdot 4 \\
4 \cdot 4 \\
-\end{array}$ \\
\hline & Left & $\begin{array}{l}18 / 2 / 52 \\
20 / 2 / 52 \\
21 / 2 / 52\end{array}$ & $\begin{array}{l}55 \cdot 1 \\
54 \cdot 1\end{array}$ & $\frac{\infty}{67}$ & $\frac{-}{8}$ & $\overline{8 \cdot 1}$ \\
\hline \multirow{2}{*}{$1409 / 51$} & Right & $\begin{array}{l}16 / 4 / 51 \\
17 / 4 / 51\end{array}$ & $\begin{array}{c}55 \cdot 9 \\
-\end{array}$ & $\begin{array}{c}22 \cdot 7 \\
-\end{array}$ & $\overline{23 \cdot 4}$ & $\overline{4 \cdot 6}$ \\
\hline & Left & $\begin{array}{r}7 / 4 / 51 \\
16 / 4 / 51 \\
17 / 4 / 51\end{array}$ & $\begin{array}{c}6 \overline{63} \cdot 8 \\
-\end{array}$ & $\begin{array}{c}\overline{18 \cdot 7} \\
-\end{array}$ & $\begin{array}{c}32 \cdot 3 \\
\overline{45 \cdot 3}\end{array}$ & $\begin{array}{l}13 \cdot 5 \\
\overline{15 \cdot 3}\end{array}$ \\
\hline $279 / 52$ & Left & $19 / 1 / 52$ & 46 & $28 \cdot 7$ & - & - \\
\hline $2694 / 51$ & Left & $6 / 7 / 51$ & $58 \cdot 9$ & $\infty$ & - & - \\
\hline $5641 / 48$ & Left & $\begin{array}{l}13 / 2 / 52 \\
14 / 2 / 52\end{array}$ & 76 & $\stackrel{\infty}{-}$ & $\overline{17 \cdot 2}$ & $\overline{4 \cdot 2}$ \\
\hline $1875 / 51$ & Left & $9 / 5 / 51$ & 90 & $\infty$ & - & - \\
\hline $1082 / 51$ & Left & $\begin{array}{l}19 / 3 / 51 \\
20 / 3 / 51\end{array}$ & $\underline{60}$ & 90 & $\overline{11 \cdot 4}$ & $\overline{3 \cdot 8}$ \\
\hline \multirow[t]{2}{*}{$1084 / 51$} & Right & $\begin{array}{l}5 / 4 / 51 \\
6 / 4 / 51 \\
7 / 4 / 51\end{array}$ & $\begin{array}{l}49 \cdot 5 \\
90\end{array}$ & $\frac{8 \cdot 9}{100}$ & $\overline{16 \cdot 7}$ & $\overline{6 \cdot 7}$ \\
\hline & Left & $14 / 4 / 51$ & - & - & $20 \cdot 1$ & $6 \cdot 6$ \\
\hline
\end{tabular}

Decrease in resistance also follows iridencleisis. After the operation, the values of resistance and tension go through three stages:

(a) A few days after the operation, the resistance is greatly diminished and may even be below normal. At the same time the ocular tension is also below normal.

(b) In the weeks following the intervention, the resistance and the ocular tension both increase slightly to reach normal values.

(c) These conditions remain steady for months or even years (Table II, opposite). The instillation of a miotic in the hypertensive eye or iridencleisis is likely 
TABLE II

\begin{tabular}{|c|c|c|c|c|}
\hline Case No. & Eye & Time since Iridencleisis & Ocular Tension & Resistance \\
\hline \multirow[t]{2}{*}{$342 / 41$} & Right & 18 months & $13 \cdot 4$ & $3 \cdot 6$ \\
\hline & Left & 18 months & $17 \cdot 5$ & $3 \cdot 1$ \\
\hline $1134 / 51$ & Left & $\begin{array}{l}9 \text { days } \\
20 \text { days } \\
40 \text { days } \\
70 \text { days }\end{array}$ & $\begin{array}{r}8 \cdot 8 \\
10 \cdot 8 \\
10 \cdot 8 \\
11 \cdot 1\end{array}$ & $\begin{array}{l}2 \cdot 7 \\
3 \cdot 3 \\
4 \cdot 1 \\
5 \cdot 1\end{array}$ \\
\hline $4154 / 48$ & Left & 3 years & $19 \cdot 7$ & $5 \cdot 9$ \\
\hline \multirow{2}{*}{$754 / 52$} & Right & 8 days & 8 & $1 \cdot 1$ \\
\hline & Left & 15 days & $11 \cdot 2$ & $3 \cdot 7$ \\
\hline $341 / 39$ & Left & 3 years & $22 \cdot 5$ & $4 \cdot 8$ \\
\hline $6278 / 48$ & Left & 3 years & $14 \cdot 2$ & $4 \cdot 7$ \\
\hline \multirow[t]{2}{*}{$1409 / 51$} & Right & $\begin{array}{l}7 \text { days } \\
25 \text { days } \\
35 \text { days } \\
2 \text { months } \\
4 \text { months }\end{array}$ & $\begin{array}{l}10 \cdot 4 \\
21 \cdot 5 \\
17 \cdot 5 \\
14 \cdot 4 \\
16 \cdot 7\end{array}$ & $\begin{array}{r}3 \cdot 3 \\
2 \cdot 6 \\
10 \cdot 8 \\
7 \cdot 1 \\
8 \cdot 1\end{array}$ \\
\hline & Left & $\begin{array}{l}7 \text { days } \\
35 \text { days } \\
2 \text { months } \\
4 \text { months }\end{array}$ & $\begin{array}{r}9 \cdot 4 \\
18 \cdot 1 \\
14 \cdot 7 \\
8 \cdot 8\end{array}$ & $\begin{array}{r}4 \cdot 8 \\
10 \cdot 6 \\
11 \cdot 4 \\
7 \cdot 3\end{array}$ \\
\hline $1557 / 33$ & Right & $\begin{array}{l}9 \text { years } \\
9 \text { years }\end{array}$ & $\begin{array}{c}10 \cdot 4 \\
8\end{array}$ & $\begin{array}{l}2 \cdot 4 \\
2 \cdot 9\end{array}$ \\
\hline \multirow[b]{2}{*}{$1082 / 51$} & Right & $\begin{array}{l}3 \text { years } \\
3 \text { years } \\
3 \text { years } \\
3 \text { years } \\
3 \text { years }\end{array}$ & $\begin{array}{c}12 \cdot 2 \\
14 \\
10 \cdot 8 \\
9 \cdot 8 \\
12 \cdot 4\end{array}$ & $\begin{array}{l}4 \cdot 6 \\
2 \cdot 7 \\
4 \cdot 4 \\
4 \cdot 3 \\
2 \cdot 9\end{array}$ \\
\hline & Left & $\begin{array}{l}7 \text { days } \\
20 \text { days } \\
35 \text { days } \\
50 \text { days } \\
3 \text { months } \\
4 \text { months } \\
5 \text { months } \\
6 \text { months }\end{array}$ & $\begin{array}{l}10 \\
18 \cdot 1 \\
16 \cdot 9 \\
20 \cdot 1 \\
18 \cdot 1 \\
16 \cdot 4 \\
18 \cdot 1 \\
16 \cdot 2\end{array}$ & $\begin{array}{c}1 \\
6 \cdot 6 \\
8 \cdot 1 \\
6 \cdot 4 \\
7 \cdot 5 \\
10 \cdot 5 \\
4 \\
7 \cdot 6\end{array}$ \\
\hline \multirow[t]{2}{*}{$1668 / 51$} & Right & $\begin{array}{l}3 \text { years } \\
3 \text { years } \\
3 \text { years }\end{array}$ & $\begin{array}{l}20 \cdot 8 \\
14 \cdot 7 \\
19 \cdot 4\end{array}$ & $\begin{array}{l}5 \\
4 \cdot 5 \\
6.6\end{array}$ \\
\hline & Left & 1 year & $32 \cdot 9$ & $6 \cdot 3$ \\
\hline $1084 / 51$ & Left & $\begin{array}{l}6 \text { days } \\
50 \text { days }\end{array}$ & $\begin{array}{l}15 \\
13 \cdot 2\end{array}$ & $\begin{array}{r}5 \cdot 9 \\
14 \cdot 4\end{array}$ \\
\hline
\end{tabular}


TABLE II-continued

\begin{tabular}{|c|c|c|c|c|}
\hline Case No. & Eye & Time since Iridencleisis & Ocular Tension & Resistance \\
\hline $2694 / 51$ & Left & $\begin{array}{l}45 \text { days } \\
80 \text { days }\end{array}$ & $\begin{array}{l}11 \cdot 1 \\
13 \cdot 4\end{array}$ & $\begin{array}{l}5 \cdot 8 \\
6\end{array}$ \\
\hline \multirow{2}{*}{$5641 / 48$} & Right & 9 days & $14 \cdot 2$ & $3 \cdot 3$ \\
\hline & Left & 14 days & $15 \cdot 6$ & $4 \cdot 4$ \\
\hline $4082 / 51$ & Right & 20 days & $15 \cdot 3$ & $4 \cdot 9$ \\
\hline $1875 / 51$ & Left & $\begin{array}{l}15 \text { days } \\
30 \text { days }\end{array}$ & $\begin{array}{l}17 \\
6 \cdot 2\end{array}$ & $\begin{array}{l}3 \cdot 2 \\
2 \cdot 9\end{array}$ \\
\hline
\end{tabular}

to reduce the resistance in the fellow eye when this is increased. In two cases where the fellow eye had presented a consensual raised resistance, acute glaucoma occurred and had to be treated surgically. The consensual increase of the resistance would therefore mean a predisposition to hypertension. This increase in the resistance without hypertension is asymptomatic. Only through the compression test can it be elicited.

\section{Discussion}

The researches of Grant $(1950,1951)$ and ourselves, with the electronic tonometer, show that most cases of ocular hypertension are due, totally or partially, to an increase of the resistance to the aqueous flow. Using another method, Goldmann (1951) reached the same conclusion.

The increase of the resistance to the aqueous flow exists in chronic simple glaucoma and in many forms of secondary glaucoma. This work shows that the pathological increase of the resistance is particularly marked in congestive glaucoma.

In congestive glaucoma, the increase of the resistance to the flow is generally and completely reversible, and is not therefore due to a permanent organic lesion. At first sight, one would be tempted to attribute it to the closure of the irido-corneal angle; in fact, during the hypertensive phase of congestive glaucoma, the angle is closed and the resistance raised. Between the crises, the resistance is normal and the angle, although often very narrow, is open. This explanation, however, is not entirely satisfactory, for we noted in certain cases that after the crisis, the resistance returned to normal whereas the angle remained apparently closed.

It seems to many workers as to ourselves, that the closure of the angle during the hypertensive phase in congestive glaucoma is not the primary phenomenon, but only the consequence of a uveal vascular phenomenon located in the anterior segment of the eye. This is the reason why we are inclined to attribute the changes in the resistance to some vascular disturbance. The presence of temporary consensual changes in the resistance of the fellow eye upholds this theory. 
Pilocarpine greatly decreases the resistance to the flow. In congestive glaucoma, this miotic opens the irido-corneal angle but has also a vasodilator effect. Therefore it may act on the angle or on the anterior uveal vessels.

The action of iridencleisis presents an important and difficult problem (Weekers and Weekers, 1949). In congestive glaucoma, some days after the iridencleisis, the resistance and the ocular tension both fall below normal. At this time, the existence of a fistula is obvious, but in the majority of cases this is only a passing phase. Some weeks later, the resistance and the ocular tension return to normal, and this contradicts the theory of a permanent fistulization. Actually, before the iridencleisis and between the hypertensive crises, the resistance to the flow is normal. Supposing that a permanent fistula existed after the operation, the compression test should reveal a permanent diminution of resistance, but, as we have shown*, this conclusion is not in accordance with the facts.

\section{Summary}

(1) The compression test performed with the electronic tonometer makes it possible to measure the resistance to the aqueous flow.

(2) This resistance is greatly increased in congestive glaucoma during the hypertensive phase. It is sometimes temporarily increased in the fellow eye, even though the tension in this eye remains normal. Between the hypertensive crises, the resistance to the flow is normal both in the glaucomatous and in the fellow eye.

(3) The instillation of pilocarpine restores the resistance to the flow to normal in cases where it restores a normal ocular tension.

(4) After iridencleisis, the resistance to the flow at first falls below normal then returns to normal.

\footnotetext{
* In a case of bilateral congestive glaucoma we performed an iridectomy on one eye and an iridencleisis on the other. Both operations restored the resistance and the tension to normal. The hypothesis of a fistulization cannot be applied to the iridectomy. In congestive glaucoma, it is possible that iridectomy and iridencleisis both restore the flow through the natural channels.
}

\section{REFERENCES}

AsCher, K. W. (1942), Amer. J. Ophthal., 25, 1174. and SPURgeon, W. M. (1949). Ibid., 32, June, Part 2, p. 239.

DUKe-EldeR, S. (1952). Ibid., 35, 1.

GoldmanN, H. (1951). Docum. ophthal., Den Haag, 5-6, 278.

Grant, W. M. (1950). Arch. Ophthal., Chicago, 44, 204. (1951). Ibid., 46, 113.

LöHLEIN, H. (1951). Ber. dtsch. ophthal. Ges., 56, 146

Moses, R. A., and Bruno, M. (1950). Amer. J. Ophthal., 33, 389.

Prijot, E., and WeEkers, R. (1952a). Ophthalmologica, Basel, 123, 1. (1952b). Ibid., 124, 12.

Thomassen, T. L. (1947). Acta ophthal., Kbh., 25, 369.

Perkins, E. S., and Dobree, J. H. (1950). British Journal of Ophthalmology, 34, 221.

WeEkERS, L., and WeEKERS, R. (1949). Ophthalmologica, Basel, 117, 305.

Weekers, R. (1947). Ann. Oculist., Paris, 180, 10.

and PrIJOT, E. (1952a). Ophthalmologica, Basel, 123, 114. (1952b). Ibid., 123, 365. (1952c). Ibid. In the press. 